\title{
Morphophysiological plasticity of plagiotropic branches in response to change in the coffee plant spacing within rows
}

\section{Plasticidade morfofisiológica de ramos plagiotrópicos do cafeeiro à variação do espaçamento na linha de plantio}

\author{
Cláudio Pagotto Ronchi ${ }^{*}$; Wellington Luiz de Almeida ${ }^{2}$; \\ Daniela Silva Souza ${ }^{3}$; José Márcio de Sousa Júnior ${ }^{4}$; \\ Antonia Mirian Nogueira de Moura Guerra5; Paulo Henrique Chaves Pimenta ${ }^{6}$
}

\begin{abstract}
Changes in spacing within rows may alter the morphology of the coffee plant by affecting the physiological constituents of its productivity. Even though some common plant responses to crop spacing variation are known, there is yet no scientific evidence that elucidates the effects of decreased spacing on the sourcesink relation in plagiotropic branches and, its association with both productivity and eco-physiological aspects of coffee leaves, mainly for new coffee cultivars in the Brazilian savannah. The aim of this work was to characterize the morphophysiological responses of Coffea arabica L. cultivars subjected to different spacing between plants within rows. Four Arabica coffee cultivars (Catuaí Vermelho IAC 144, Catuaí Amarelo IAC 62, Catuaí Amarelo IAC 32, and Tupi RN IAC 1669-13) were transplanted in January 2010. A row spacing of $0.40,0.50,0.60,0.70$, and $0.80 \mathrm{~m}$ was adopted between plants, maintaining a $3.80-\mathrm{m}$ constant between rows. A randomized block design with four replicates was applied. During the experimental period, several morphophysiological characteristics of plagiotropic fruiting branches were evaluated in the months of April and December in 2013 and, in April 2014. The evaluation was conducted based on two canopy positions; canopy toward the rows, representing low exposure to light or toward the inter-row spacing, representing high light exposure. Leaf gas exchange, chlorophyll fluorescence, and photosynthetic pigments levels were minimally or not at all affected by changing either the coffee cultivars or plant spacing. During the first evaluation, the leaf-to-fruitratio linearly increased, regardless of the cultivar. Light-exposed branches showed higher content of carotenoids and chlorophyll $a$ in leaves and lower leaf-to-fruit-ratio as compared to those within the plant canopy. A major reduction in the number of fruits per branch was observed which was closely related to a parallel decrease in the number of fruits per node but not in the number of fruiting nodes per branch. Although this response was largely cultivar-dependent, it also changed according to the branch position in the hedgerow. Our results suggest that all tested cultivars exhibit high morphophysiological plasticity and have the potential to grow under different plant spacing within rows.
\end{abstract}

Key words: Coffea arabica. Gas exchange. High-density planting. Leaf area. Source/sink relationship.

\footnotetext{
${ }^{1}$ Prof. Associado, Universidade Federal de Viçosa, UFV, Forestal, MG, Brasil. E-mail: claudiopagotto@ufv.br

2 M.e em Agronomia, UFV, Viçosa, MG, Brasil. E-mail: almeida-wl@hotmail.com

${ }^{3}$ Enga Agra $^{\mathrm{a}}$ UFV, Rio Paranaíba, MG, Brasil. E-mail: danielasouza_cp@hotmail.com

${ }^{4}$ Eng $^{\circ}$ Agr $^{\circ}$, UFV, Rio Paranaíba, MG, Brasil. E-mail: josemarcio_18@hotmail.com

${ }^{5}$ Prof $^{a}$ Adjunta, Universidade Federal do Oeste da Bahia, UFOB, Barra, BA, Brasil. E-mail: mirianagronoma@hotmail.com

${ }^{6}$ Discente de Graduação em Biologia, UFV, Rio Paranaíba, MG, Brasil. E-mail: ph.chavez@hotmail.com

* Author for correspondence
} 


\section{Resumo}

A variação do espaçamento dentro da linha de plantio pode interferir na morfologia do cafeeiro, alterando seus componentes de produtividade. Apesar de algumas respostas gerais à variação do espaçamento serem conhecidas, nenhum trabalho anteriormente demonstrou como e quanto a redução do espaçamento na linha altera a relação fonte: dreno de ramos plagiotrópicos, associando-a com os componentes de produtividade e com aspectos ecofisiológicos foliares. Isso considerando as modernas tecnologias e cultivares em uso no Cerrado. O objetivo deste trabalho foi quantificar as respostas morfofisiológicas em ramos plagiotrópicos de cultivares de Coffea arabica L. submetidas a diferentes espaçamentos na linha de plantio. Os cultivares Catuaí Vermelho IAC 144, Catuaí Amarelo IAC 62, Catuaí Amarelo IAC 32 e Tupi RN IAC 1669-13 foram plantados em janeiro de 2010, no espaçamento de 3,80 m entre linhas, adotando-se os espaçamentos de $0,40,0,50,0,60,0,70$ e $0,80 \mathrm{~m}$ entre plantas na linha. O delineamento foi em blocos casualizados, com quatro repetições. Em abril e dezembro de 2013 e, também, em abril de 2014, foram feitas diversas avaliações morfofisiológicas em ramos produtivos (com carga pendente) posicionados no sentido da linha ou perpendicularmente a esta (portanto, menos ou mais exposto à luz, respectivamente). As trocas gasosas, os parâmetros de fluorescência e os níveis de pigmentos foram pouco ou nada afetados pelas cultivares e espaçamentos. A razão área foliar: fruto, em abril de 2013, aumentou linearmente com a redução do espaçamento, independentemente de cultivares. Em ramos mais expostos os níveis de carotenóides e clorofila $a$ foram superiores, ao passo que a razão área foliar: fruto foi inferior, em comparação a ramos mais internos. $O$ decréscimo do espaçamento entre plantas na linha reduziu linearmente o número de frutos por ramo, em função da redução no número de frutos por roseta e não do número de nós por ramo, e a intensidade dessa resposta variou, sobretudo com a cultivar, mas também com a posição do ramo na planta. As cultivares avaliadas apresentaram alta plasticidade para cultivo em diferentes espaçamentos.

Palavras-chave: Adensamento. Área foliar. Coffea arabica. Trocas gasosas. Relação fonte: Dreno.

\section{Introduction}

Coffea arabica production in the Brazilian Cerrado region is concentrated in the state of Minas Gerais (FERNANDES et al., 2012) particularly in the Alto Paranaiba, Northwestern and Triangulo Mineiro regions, where the estimated production for 2016 is 6.502 million sacks (CONAB, 2016). In this region, the crops are planted in open rows to allow mechanized cultivation and harvesting and to facilitate cultural practices (MATIELLO et al., 2010; FERNANDES et al., 2012). Thus, for small sized varieties like Catuaí, which are widely grown in the Cerrado region, the spacing commonly practiced is $4.0 \mathrm{~m} \times 0.5 \mathrm{~m}(\mathrm{CARVALHO}, 2008$; SANTINATO et al., 2008; MATIELLO et al., 2010).

Although the definition of the best plant spacing depends on variables such as cultivar, plant size, topography and management conditions, the proper distribution of plants within and between rows may significantly increase the productivity per area (SANTINATO et al., 2008; MATIELLO etal., 2010).
For example, Andrade et al. (2014) showed more productive combinations for the same population of plants per hectare when the spacing between plants in the row was used decreased; Paulo et al. (2005) also observed increased productivity with higher plant density by reducing the spacing between lines, even though the yield per plant was lower. Moreover, a reduction in the spacing between plants appears to reduce the individual production of each plant as against reducing the spacing between rows (AUGUSTO et al., 2006).

Studies on adaptability and stability of cultivars demonstrate that different coffee cultivars may present different results when subjected to changes in farming environments (BOTELHO et al., 2010; NASCIMENTO et al., 2010; PARTELLI et al., 2014). Morphophysiological changes have been observed in coffee in response to environmental variations (NASCIMENTO et al., 2006; FERREIRA et al., 2013; PEREIRA et al., 2013; RODRÍGUEZLÓPEZ et al., 2014), especially variation of light 
intercepted by branch leaves in different canopy positions (ARAUJO et al., 2008; MATOS et al., 2009; CHAVES et al., 2012). Reduction in the planting spacing both between rows and between plants in a row resulted in greater height of the primary orthotropic branch (RENA et al., 2003; PEREIRA; CUNHA, 2004; PAULO et al., 2005), lower stem diameter and canopy base (PAULO et al., 2005), caused more intense necrosis of plagiotropic branches in the lower third of the coffee plant (MATIELLO et al., 2010; PEREIRA; CUNHA, 2004), and decreased the productive area of each plant (PEREIRA; CUNHA, 2004), justifying the fact that disuse of spacing below 0.5 $\mathrm{m}$ between plants in the row. In plants with row spacing greater than $0.7 \mathrm{~m}$, low soil surface cover, total photosynthetic production, and grain yield may be far below potential (CANNELL, 1985).

Coffee is morphophysiologically acclimatized to grow in shade adjustments for this type of environment, but it is also seen to adapt well to an unshaded environment (ARAUJO et al., 2008; TATAGIBA et al., 2010), since it has mechanisms to adjust its photosynthetic machinery to the prevailing light conditions (DaMATTA, 2004). The practice of coffee cultivation in sunlight has presented problems such as overproduction and the consequent depletion of plants during the early years until self-shading decreases this effect (DaMATTA et al., 2007). Therefore, even if productivity does not increase in denser crops, depending on self-shading, the lower individual productivity per plant can contribute to reducing the productivity biannually and increasing crop longevity.

Ongoing research is focused on the development of highly productive and disease-resistant varieties with other important agronomic traits, such as high quality beverage and fitness to denser plantations (CARVALHO, 2008; BLISKA et al., 2011). Nonetheless, the increasing use of fertigation and new technologies in the management of crops requires an exact definition of plant spacing within the row for each cultivar. Furthermore, considering that many of these cultivars have only recently been introduced in the Cerrado, it is of importance to know their productive plasticity, in particular the plasticity of the physiological components under different plant spacing. Therefore, the aim of this study was to characterize the morphological and physiological responses of four Coffea arabica L. cultivars subjected to different spacing in a planting row in the Cerrado region.

\section{Materials and Methods}

The experimental area was located in the Transagro farm in the municipality of Rio Paranaiba, Minas Gerais (19 $13^{\prime} 0.90^{\prime \prime} \mathrm{S}$ and $46^{\circ} 20^{\prime} 36.16^{\prime \prime} \mathrm{W}$, Altitude: $906 \mathrm{~m}$ ) belonging to the Alto Paranaíbaregion. The soil in the experimental area is a dystrophic red-yellow latosol, with clayey texture and a gentle-wavy relief (MOTTA et al., 2004), presenting at $0-20 \mathrm{~cm}$ layer the following chemical properties: $\mathrm{pH}-5.83$; organic matter content (33.7 $\mathrm{g} \mathrm{kg}^{-1} ; \mathrm{V} \%$ 46.5; m\% 2.5; P $0.84 \mathrm{mg} \mathrm{dm}^{-3} ; \mathrm{K} 250 \mathrm{mg}$ $\mathrm{dm}^{-3}$; Ca 1,60 $\mathrm{cmol}_{\mathrm{c}} \mathrm{dm}^{-3} ; \mathrm{Mg} 0.47 \mathrm{cmol}_{\mathrm{c}} \mathrm{dm}^{-3}$, and CTC (T) $5.70 \mathrm{cmol}_{\mathrm{c}} \mathrm{dm}^{-3}$ ). According to Köppen, the climate is Cwa, semi-wet tropical zone, with the presence of two distinct seasons: hot and rainy summer and dry and cold winter (FERNANDES et al., 2012).

The study was initiated in January 2010 in a commercial farm with four $C$. arabica $\mathrm{L}$. cultivars (Catuaí Vermelho IAC 144, Catuaí Amarelo IAC 62, Catuaí Amarelo IAC 32, and Tupi RN IAC 166913). These cultivars were selected because they are widely used in mechanized coffee areas (IAC 144) and have high potential in the Cerrado region due to the yellow color of fruits and high adaptability (IAC 62 and IAC 32), resistance to rust and nematodes (Tupi RN) and high quality drink (CARVALHO, 2008). Seedlings with four pairs of leaves were transplanted in furrows, in accordance with the planting methods prevalent in the Cerrado region (SANTINATO et al., 2008), with spacing of 3.80 $\mathrm{m}$ between rows. The spacing between plants was 
confined within the extreme limits for mechanized cultivation, since spacing between plants of less than $0.5 \mathrm{~m}$ or greater than $0.7 \mathrm{~m}$ are rarely used in the region for small sized varieties (MATIELLO et al., 2010). Spacing of $0.40,0.50,0.60,0.70$, and $0.80 \mathrm{~m}$ between plants was tested to obtain approximately $6.580,5.260,4.390,3.760$, and 3.290 plants per hectare, respectively. The experimental design was a randomized block with four replications. Blocks were arranged in the planting row, with ten plants per experimental unit.

Cultivation during the growing season involved weed control with herbicides, mowing or brushing, plant management, liming in the planting row and application of water and fertilizers (fertigation) through a drip system in the entire experimental area. Irrigation management was done from September to May. The irrigation system was turned on $\left(8 \mathrm{~h} \mathrm{day}^{-1}\right)$ whenever the initial readily available water reached the value of $50 \%$, bringing it up to at least $80 \%$. During the 2013-2014 agricultural years, 407, 162, and $387 \mathrm{~kg} \mathrm{ha}^{-1}$ of $\mathrm{N}, \mathrm{P}_{2} \mathrm{O}_{5}$, and $\mathrm{K}_{2} \mathrm{O}$ were applied, respectively. Dolomitic limestone $\left(677 \mathrm{~kg} \mathrm{ha}^{-1}\right)$ and chicken manure (1.531 kg ha-1) were also used.

Three collection periods were identified during two important phenological stages of the culture for evaluating the plagiotropic branches. Collections were made in April 2013 and 2014 in the final fruit-filling phase and in December 2013, at the stage of rapid expansion of fruits, which also had the highest vegetative growth rates (DaMATTA et al., 2007). Approximately 1.5 hours after the start of the photoperiod, between $07 \mathrm{~h} 30$ and 09h30, evaluations of gas exchange and fluorescence parameters of chlorophyll $a$ were performed in fully expanded leaves. The leaf samples were taken from either the third or fourth pair from the apical region of reproductive branches (bearing branches) of the middle third of plants, in branches positioned both in parallel (position 1) and perpendicular (position 2) to the planting line. In position 1, branches were located inside the canopy and in position 2 they faced toward the line space. Liquid carbon assimilation rates $(A)$, stomatal conductance $\left(g_{\mathrm{s}}\right)$ and transpiration $(E)$ were measured according to Ronchi et al. (2015a). The excitation energy capture efficiency by open reaction centers of FSII $\left(F_{\mathrm{v}}{ }^{\prime} / F_{\mathrm{m}}{ }^{\prime}\right)$, the photochemical quenching coefficient $(q \mathrm{P})$ and the quantum yield of electron transport $\left(\varphi_{\mathrm{FSII}}\right)$ were measured simultaneously with the gas exchange using a portable infrared gas analyzer with integrated fluorescence (LIQUOR 6400XT, LI-COR, Lincoln, USA). Evaluations of the blocks were made in the morning on two consecutive days. Leaf discs were collected at noon and frozen immediately in liquid nitrogen to quantify the levels of chlorophyll $a$ and $b$, total chlorophyll and carotenoids (RONCHI et al., 2006).

The plagiotropic branches used for the experiments in all three collection periods were retrieved in Styrofoam boxes. In the laboratory, the fruits and leaves were detached, separated, and counted. The length, number of nodes in the branch and the number of fruits per node were also assessed. The total leaf area was measured in a bench meter (LI-3000CAP, LI-COR, Lincoln, USA) and the leaves, fruits and stems were dried in the oven at $70^{\circ} \mathrm{C}$ for $72 \mathrm{~h}$ and weighed. The data collected were used to calculate the following: i) fruit dry mass by total branch dry mass (RMFr), ii) stem dry matter by total branch dry mass (RMR), iii) leaf dry mass by total branch dry mass (RMFo), iv) leaf area by total branch dry weight (RAF), v) leaf area by number of fruits in the branch (RAFFr), and vi) fruit dry mass by number of fruits, or, dry matter per fruit.

A joint analysis of variance was conducted with data of the four cultivars, using a hierarchical factorial scheme (where cultivars were allocated within blocks), with assessment of significant interactions of interest. To compare the means of features relating to cultivars or branch positions and their positions within the different spacing, the Tukey test was used, adopting a 5\% level of probability. To check the influence of spacing and its influence on the levels of cultivars or branch positions, regression models were chosen based 
on the significance of regression coefficients, the coefficient of determination, and biological performance. Data for each collection time were analyzed separately. Characteristics evaluated but not presented or mentioned in the discussion did not show significant effect on factors investigated or their interactions.

\section{Results and Discussion}

In the three periods of branch evaluation, significant interaction between cultivars and spacing for the number of fruits per branch was observed (NFr). There was a linear reduction in NFr on reducing the spacing between plants for all cultivars; however, this effect was more pronounced in IAC 32 and IAC 1669-13 cultivars in April 2013 and IAC 62 in April 2014 (Figure 1 A, C and E). Therefore, effect of spacing on the production of fruits per branch is characterized, with variations among cultivars. NFr results obtained from multiplying the number of nodes per branch by the number of fruits per node, along with the dry mass per fruit, number of branches per plant and number of plants per hectare, are physiological components of coffee productivity (CANNELL, 1985; DaMATTA et al., 2007). Since in this experiment the number of nodes per branch was not affected by spacing, a fact also verified by Rena et al. (2003), it was concluded that there was a reduction in the number of fruits per node with reduced spacing, which was actually found in all cultivars and evaluation periods (Figure $1 \mathrm{~B}, \mathrm{D}$ and F). It is noteworthy that the dry mass per fruit did not change with changed spacing especially at the final fruit filling phase and that the number of primary plagiotropic branches per plant (not evaluated) is a very stable genetic trait in many environments and changes little with the spacing variation (RENA et al., 2003). These results indicate that the lower number of fruit per node was probably due to lower floral profusion caused by self-shading (CANNELL, 1985; DaMATTA et al., 2007; FAHL et al., 2009), a crucial explanation for the lower production per plant commonly observed in dense planting (PEREIRA et al., 2011; ANDRADE et al., 2014), especially when the number of plants in the row is reduced (PEREIRA et al., 2013).

In April 2013, when evaluating the effect of spacing on variables related to the growth of plagiotropic branches, it was found that the total dry matter increased with increasing spacing (Figure 2 A) in proportion to the increase in the dry matter of fruits (Figure $2 \mathrm{~B}$ ), and not the other constituents of the branch. This means that there was a higher dry matter partitioning for fruits over leaves and branches, and this was clearly confirmed by the linear increase in the fruit mass ratio (Figure $2 \mathrm{E}$ ), whereas branches (Figure $2 \mathrm{C}$ ) and leaves (Figure 2D) were reduced with increasing spacing. Since effect of spacing on the leaf area of plagiotropic branches was not observed, despite the marked reduction in the mass ratio of leaves with increased spacing (Figure $2 \mathrm{D}$ ), with the high increase in NFr (Figure $1 \mathrm{~A}, \mathrm{C}$ and $\mathrm{E}$ ), increased spacing reduced linearly and significantly $(\mathrm{P}<0.001)$ the relationship between leaf area and NFr (RAFFr; 2 F). Thus, regardless of cultivar and position of the plagiotropic branch, it ranged from $22 \mathrm{~cm}^{2}$ fruit ${ }^{-1}$ in spacing of $0.4 \mathrm{~m}$ to $11 \mathrm{~cm}^{2}$ fruit $^{-1}$ in spacing of 0.8 $\mathrm{m}$. 
Figure 1. Effect of spacing within cultivars on the number of fruits per branch (NFr) and number of fruits per node (NFrN) in April 2013 (A and B), December 2013 (C and D) and April 2014 (E and F) in Rio Paranaiba, MG. Adjusted regressions, determination coefficients and $* *$ and $*$ : significance of coefficients $1 \%$ and $5 \%$ probability, respectively, by the $t$ test. Values refer to the mean \pm standard error of mean, $n=4$.

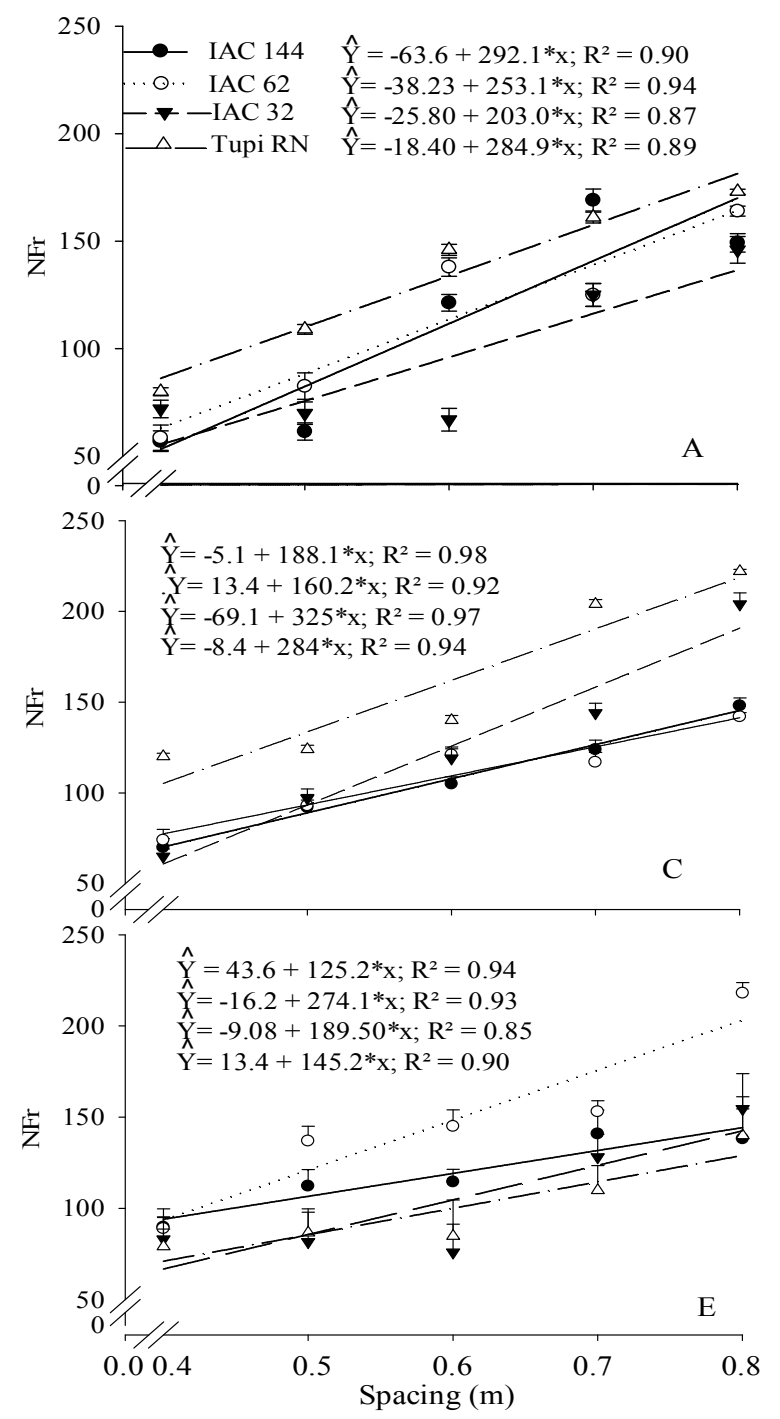

According to Cannell (1985), $20 \mathrm{~cm}^{2}$ of leaf is required for each coffee fruit. However, Chaves et al. (2012) showed that branch growth and total fruit production are reduced as RAFRr decreases, showing competition between vegetative and reproductive growth, the latter prevailing over the former, since fruits are priority sinks (CANNELL, 1985; LAVIOLA et al., 2007). In this study, the strong effect of spacing on RAFFr was demonstrated. Taken together, these results indicate that in denser crops, the marked lower yield per plant, also

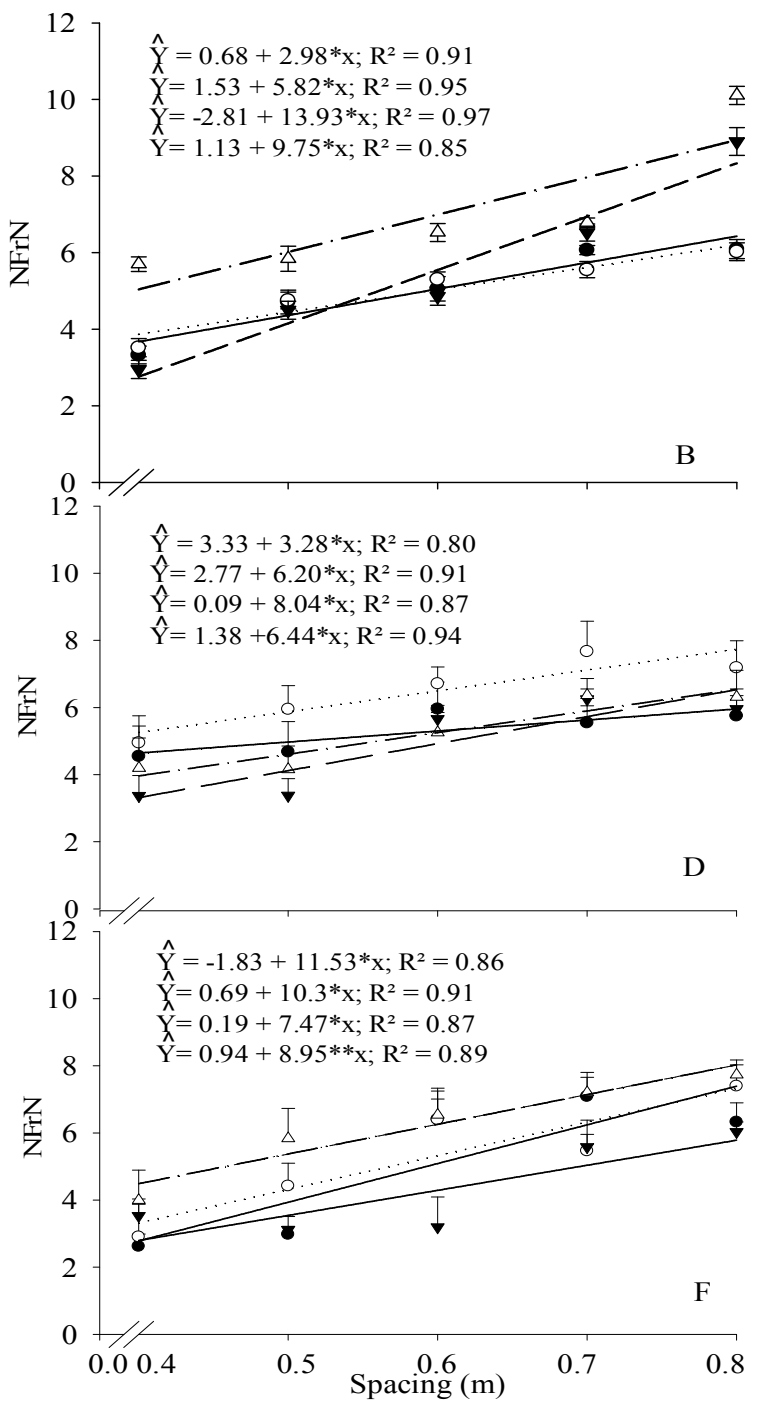

verified by Rena et al. (2003) and Andrade et al. (2014) is accompanied by a more appropriate leaf area: fruit ratio, therefore characterizing an increase in the source: sink ratio. This can contribute to lower production biannually and higher longevity of plants in denser crops, as suggested by DaMatta et al. (2007), also reducing the occurrence of dry branches, whose incidence is known to be lower in branches with higher RAFFr (CHAVES et al., 2012). 
Figure 2. Spacing factor effect on variables: A - total dry mass of the branch (MST), B - dry fruit mass per branch (MSFr), $\mathrm{C}$ - branch mass ratio (RMR), D - leaf mass ratio (RMFo), E - fruit mass ratio (RMFr) and F - relationship between total leaf area of the branch and number of fruits per branch (RAFFr) in April 2013 in Rio Paranaiba, MG. Adjusted regressions, determination coefficients and $* *$ and $*$ : significance of coefficients $1 \%$ and $5 \%$ probability, respectively. Values refer to the mean \pm standard error of mean, $\mathrm{n}=16$.
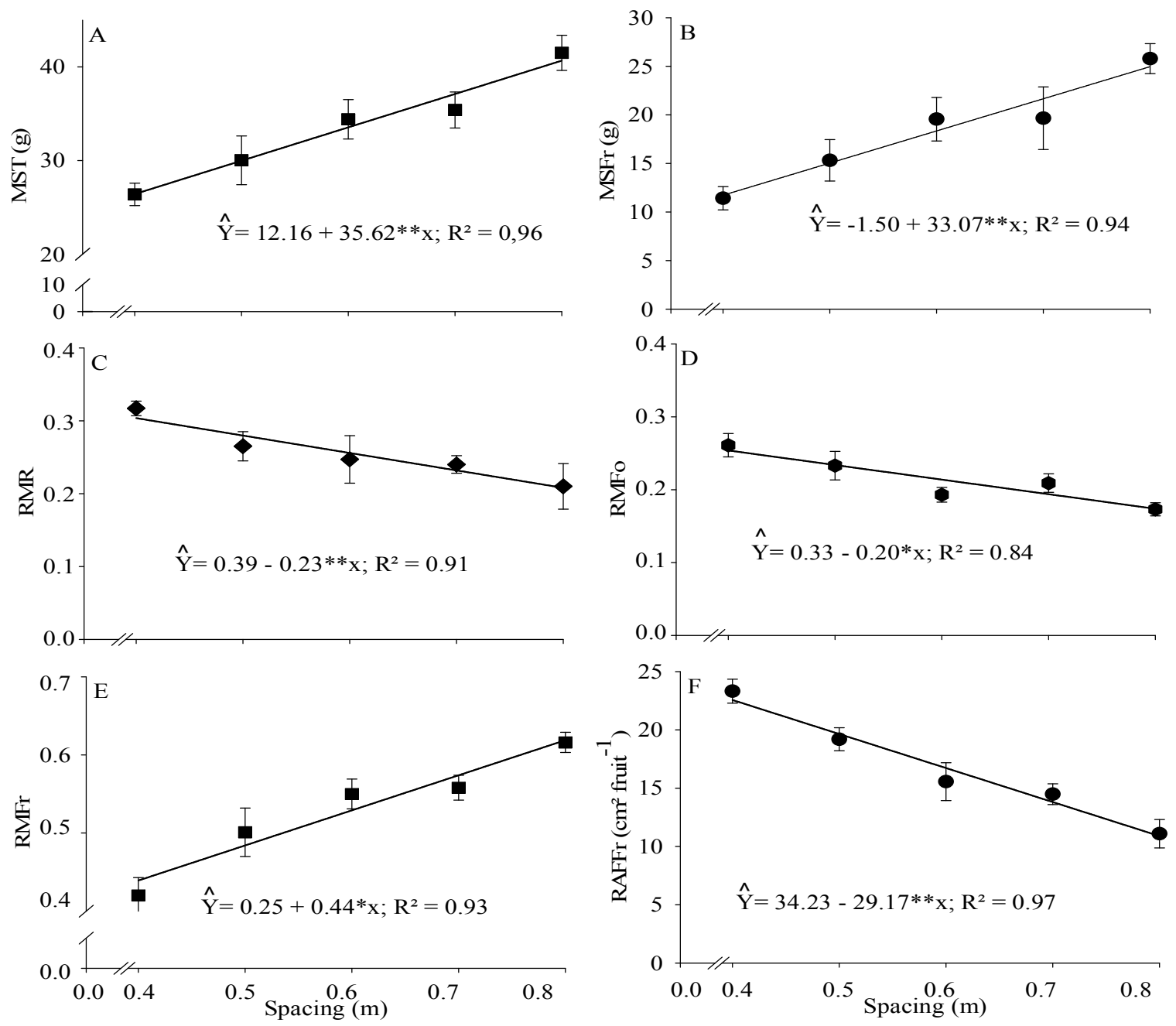

In the December evaluation, regardless of cultivar and branch position, it was found that even with the increase in the number of leaves in the branch (Figure 3A), there was a linear decrease in both RAFFr (Figure 3 B) and in the dry matter per fruit (Figure $3 \mathrm{C}$ ) with increased spacing due to the large increase in the number of fruits per branch (Figure 1-C). When fruit load is high, there is competition for carbohydrates among fruits, which may affect the final grain size, the biochemical composition and the drink quality

(VAAST et al., 2006). As a result, to sustain a high load of fruits in wider spacing, with low RAFFr, the individual mass of sinks (mass/fruit) was lowered. In December 2013, fruits had not yet entered the phase of high carbohydrate demand, which only occurred later in the fruit-filling phase (MORAIS et al., 2008; DaMATTA et al., 2007; LAVIOLA et al., 2007). In fact, in the assessment performed in April 2014, unlike that made in the previous year, the spacing factor alone did not affect variables related to plagiotropic branches, such that the RAFFr 
remained at approximately $19 \mathrm{~cm}^{2}$ fruit ${ }^{-1}$, regardless of factors investigated. As previously observed, NFr increased with increased spacing (Figure $1 \mathrm{C}$ ). Therefore, for the 2014 harvest, compatible leaf area seems to have sustained a high fruit load, even in the largest spacing, without damage to the final grain weight, showing a possible adjustment of the source: sink ratio throughout the fruiting process.

Figure 3. Spacing factor effect on the number of leaves per branch (NFo), number of fruits per branch (NFr), leaf area per fruit (RAFFr) and fruit mass by fruit number (MSFr/NFr) in December 2013 in Rio Paranaiba, MG. Adjusted regressions, determination coefficients and $* *$ and $*$ : significance of coefficients $1 \%$ and $5 \%$ probability, respectively, by the $t$ test. Values refer to the mean \pm standard error of mean, $\mathrm{n}=16$ for variables $\mathrm{A}, \mathrm{C}$ and $\mathrm{D} ; \mathrm{n}=8$ for variable $\mathrm{B}$.
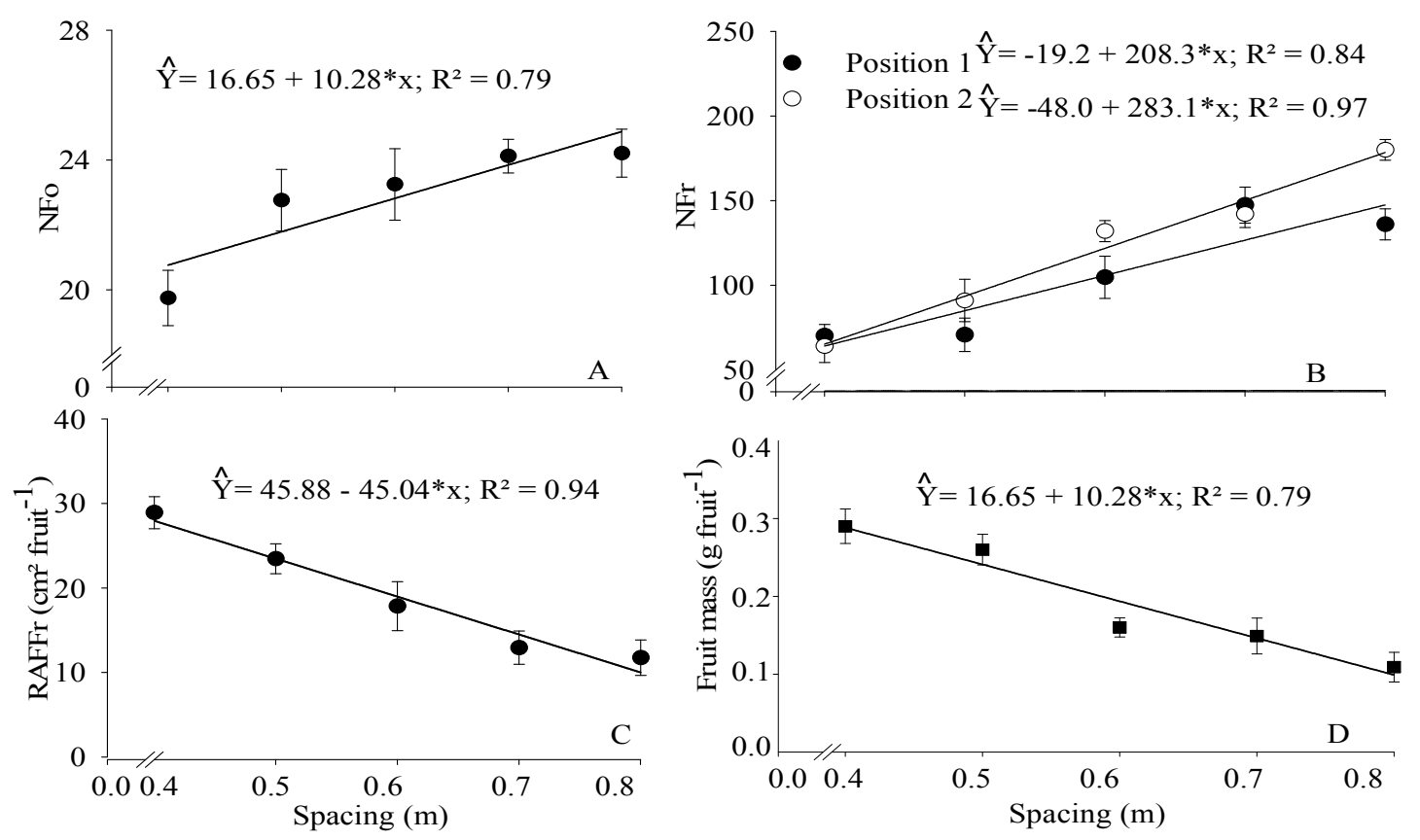

In December 2013 alone, the reduction in NFr due to the reduction in spacing was slightly more significant in branches in position 2 (facing the line spacing) compared to those in position 1 (branches parallel to the row, therefore facing the canopy) (Figure 3 D). Furthermore, branches in position 2 had RAFFr 14\% lower $\left(16.5 \mathrm{~cm}^{2}\right.$ fruit $\left.^{-1}\right)$ compared to those in position $1\left(19.33 \mathrm{~cm}^{2}\right.$ fruit $\left.{ }^{-1}\right)$ regardless of cultivar and spacing. These results corroborate the findings of Chaves et al. (2012), who found great variability in RAFFr of plagiotropic branches across different positions in the coffee canopy. The probable difference in the availability of light between positions 1 and 2 may have influenced this feature, given the known effect of light on the

morphological plasticity of the coffee crop (MATOS et al., 2009; RODRÍGUEZ-LÓPES et al., 2014), mainly on the floral profusion (CANNELL, 1985; FAHL et al., 2009). Vaast et al. (2006) observed reduction in RAFRr from $18 \mathrm{~cm}^{2}$ fruit $^{-1}$ in the shaded environment to $13 \mathrm{~cm}^{2}$ fruit ${ }^{-1}$ in coffee plants in full sunlight in two consecutive harvests.

In April 2013 the levels of chlorophyll $a$ and carotenoids were higher at 21 and $32 \%$, respectively, in branches facing the line space compared to those inside the canopy, but only in Catuaí Amarelo IAC 62 cultivar, regardless of spacing (Table 1). The higher level of carotenoids is related to photoprotection mechanisms against excessive irradiance intercepted by the leaves of the most exposed branches of 
coffee plants (MATOS et al., 2009). Furthermore, the lower chlorophyll a/carotenoid ratio (3.04; deduced from Table 1) in the most exposed branches of IAC 62 compared to more internal branches (3.52) suggests greater photo protection capacity of leaves of these branches (MATOS et al., 2009). However, the leaves of branches facing the line spacing, in this evaluation, regardless of cultivar and spacing showed higher $q \mathrm{P}$ compared to those on the line (therefore more shaded), but this did not translate into an increased $\phi_{\mathrm{PSII}}$, because, inversely, leaves facing the line spacing had lower excitement energy capture efficiency by open reaction centers of PSII $\left(F_{\mathrm{v}}{ }^{\prime} / F_{\mathrm{m}}{ }^{\prime}\right)$, compared to the others (Table 1). Similar results were obtained by Matos et al. (2009), indicating parity in the photochemical ability of coffee leaves exposed to different levels of irradiance.

Table 1. Interaction between factors cultivar and branch position in the plant on levels of chlorophyll $a$ and carotenoids, regardless of spacing, and effect of branch position on the fluorescence parameters of chlorophyll $a$ (excitation energy capture efficiency by open reaction centers of FSII $-F_{\mathrm{v}}{ }^{\prime} / F_{\mathrm{m}}{ }^{\prime}$, photochemical quenching $-\mathrm{qP}$, and quantum yield of electron transport through FSII $-\varphi_{\mathrm{FSII}}$ ), regardless of cultivar and spacing in assessment carried out in April 2013.

\begin{tabular}{|c|c|c|c|}
\hline \multirow{3}{*}{ Cultivars } & \multicolumn{3}{|c|}{ Branch position } \\
\hline & Position 1 & Position 2 & Mean \\
\hline & \multicolumn{3}{|c|}{ Level of chlorophyll $a\left(\mathrm{mmol} \mathrm{m}^{-2}\right)$} \\
\hline Catuaí Vermelho IAC 144 & $3.63 \mathrm{Aa}$ & $3.83 \mathrm{Aa}$ & 3.73 \\
\hline Catuaí Amarelo IAC 62 & $3.38 \mathrm{Ab}$ & $4.31 \mathrm{Aa}$ & 3.84 \\
\hline Catuaí Amarelo IAC 32 & 3.90Aa & $3.93 \mathrm{Aa}$ & 3.91 \\
\hline Tupi RN IAC 1669-13 & 3.99Aa & $3.86 \mathrm{Aa}$ & 3.92 \\
\hline \multirow[t]{2}{*}{ Mean } & 3.72 & 3.98 & 3.85 \\
\hline & \multicolumn{3}{|c|}{ Level of chlorophyll $b\left(\mathrm{mmol} \mathrm{m}^{-2}\right)$} \\
\hline Catuaí Vermelho IAC 144 & $1.54 \mathrm{Aa}$ & $1.47 \mathrm{Aa}$ & 1.50 \\
\hline Catuaí Amarelo IAC 62 & $1.57 \mathrm{Aa}$ & $1.28 \mathrm{Aa}$ & 1.42 \\
\hline Catuaí Amarelo IAC 32 & $1.52 \mathrm{Aa}$ & $1.64 \mathrm{Aa}$ & 1.58 \\
\hline Tupi RN IAC 1669-13 & $1.41 \mathrm{Aa}$ & $1.40 \mathrm{Aa}$ & 1.40 \\
\hline \multirow[t]{2}{*}{ Mean } & 1.50 & 1.44 & 1.49 \\
\hline & \multicolumn{3}{|c|}{ Level of carotenoids $\left(\mathrm{mmol} \mathrm{m}^{-2}\right)$} \\
\hline Catuaí Vermelho IAC 144 & $1.04 \mathrm{Aa}$ & $1.17 \mathrm{Aa}$ & 1.10 \\
\hline Catuaí Amarelo IAC 62 & $0.96 \mathrm{Ab}$ & $1.42 \mathrm{Aa}$ & 1.19 \\
\hline Catuaí Amarelo IAC 32 & $1.20 \mathrm{Aa}$ & $1.14 \mathrm{Aa}$ & 1.17 \\
\hline Tupi RN IAC 1669-13 & $1.20 \mathrm{Aa}$ & $1.20 \mathrm{Aa}$ & 1.20 \\
\hline Mean & 1.10 & 1.23 & 1.16 \\
\hline \multicolumn{4}{|c|}{ Fluorescence parameters of chlorophyll $a$ (regardless of cultivar and spacing) } \\
\hline$F_{\mathrm{v}}^{\prime} / F_{\mathrm{m}}{ }^{\prime}$ & $0.53 \mathrm{a}$ & $0.49 \mathrm{~b}$ & 0.51 \\
\hline$q \mathrm{P}^{\mathrm{m}}$ & $0.20 \mathrm{~b}$ & $0.25 \mathrm{a}$ & 0.22 \\
\hline$\varphi_{\mathrm{FSI}}$ & $0.10 \mathrm{a}$ & $0.11 \mathrm{a}$ & 0.10 \\
\hline
\end{tabular}

Means followed by the same uppercase letters in column and lowercase on the line do not differ by the Tukey test at $5 \%$ probability. Position 1: branches positioned in parallel to the planting line; Position 2: perpendicular to the planting line.

In the phase of rapid expansion of fruits or fruit filling, it was not possible to adjust any significant regression model, in any of the evaluation periods, with a biological rationale to explain the behavior of gas exchange variables $\left(A, g_{\mathrm{s}}\right.$ and $E$ - Figures 4, 5 and 6, A and B) and fluorescence parameters of chlorophyll $a\left(q \mathrm{P}, F_{\mathrm{v}}^{\prime} / F_{\mathrm{m}}^{\prime}\right.$ e $\left.\phi_{\text {PSII }}\right)$ as a function of spacing (and their interactions) to any cultivar. Therefore, there was no increase in the photochemical performance of FSII or in liquid $\mathrm{CO}_{2}$ uptake rate per unit leaf area to compensate for the reduced source: sink ratio (decrease in RAFFr) 
observed with increased spacing between plants. handling of the source: sink ratio, the defoliation These results corroborate Chaves et al. (2012), and/or defruiting and the girdling significantly who also detected no changes in $A$ and $g_{\text {s }}$ even with changed the photosynthetic rates (VAAST et al., large natural variations, in RAFFr. However, this 2005; FRANCK et al., 2006; DaMATTA et al., behavior is not standard for coffee, given that the 2008).

Figure 4. Effect of cultivar factor on variables: $\mathrm{A}$ - net $\mathrm{CO}_{2}$ assimilation rate $(A), \mathrm{B}$ - stomatal conductance $\left(g_{\mathrm{s}}\right), \mathrm{C}-$ number of fruits per branch (NFr), D - number of nodes per branch (NNodes) and fruit per node (NFrN), E - leaf area of the branch (AFo), $\mathrm{F}$ - mass ratios of branch (RMR), fruits (RMFr) and leaves (RMFo), G - relationship between leaf area and number of fruits per branch (RAFFr), and $\mathrm{H}$ - fruit mass on April 2013 in Rio Paranaiba, MG. Columns followed by the same letter do not differ by the Tukey test at $5 \%$ probability. Each column refers to the average \pm standard error of mean, $n=20$.
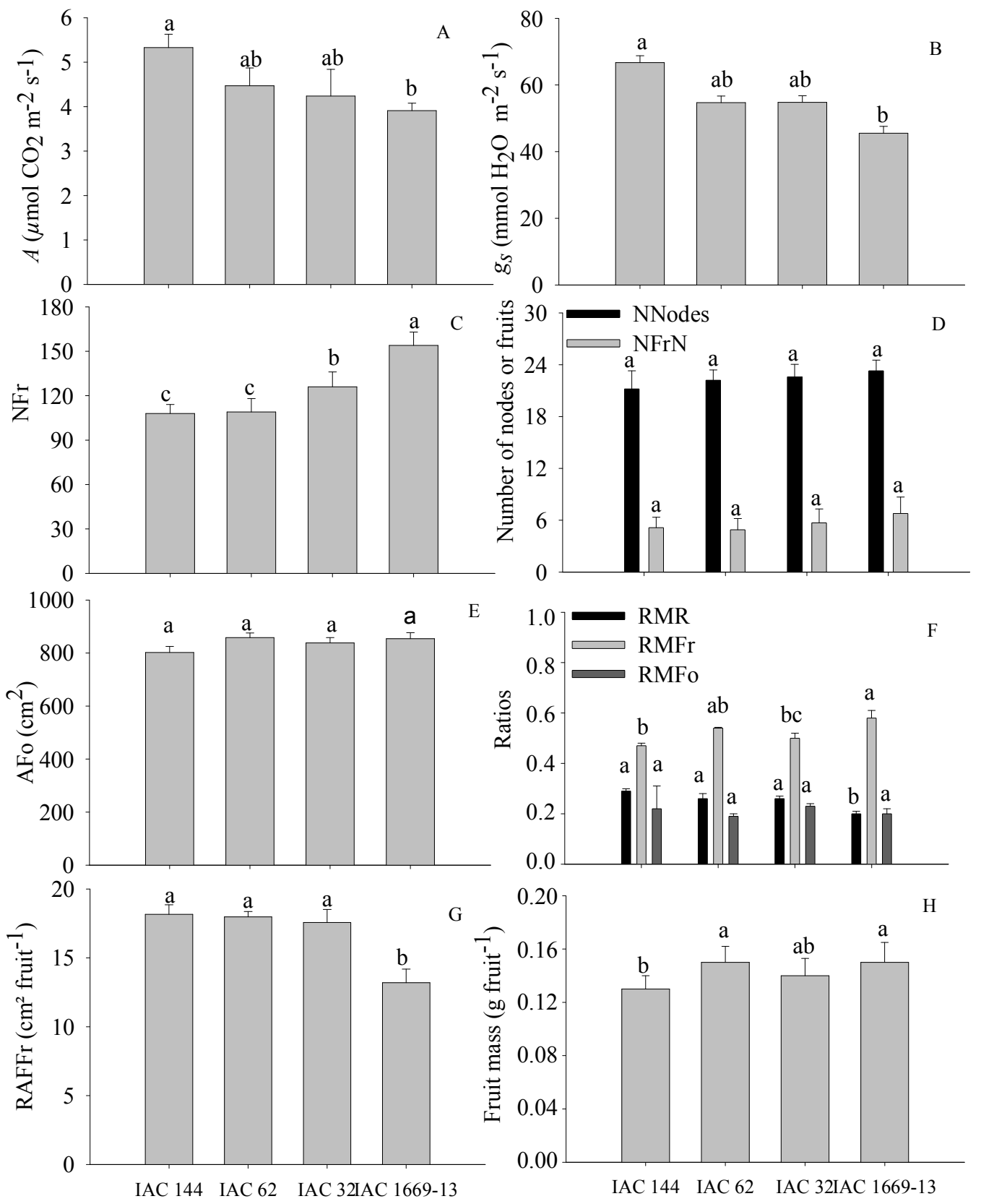
Figure 5. Effect of cultivar factor on variables: $\mathrm{A}$ - net $\mathrm{CO}_{2}$ assimilation rate $(A), \mathrm{B}$ - stomatal conductance $\left(g_{\mathrm{s}}\right)$, $\mathrm{C}$ - number of fruits per branch (NFr), D - number of nodes per branch (NNodes) and fruit per node (NFrN), E leaf area of the branch (AFo), F - mass ratios of branch (RMR), fruits (RMFr) and leaves (RMFo), G - relationship between leaf area and number of fruits per branch (RAFFr), and H - fruit mass in December 2013 in Rio Paranaiba, MG. Columns followed by the same letter do not differ by the Tukey test at $5 \%$ probability. Each column refers to the average \pm standard error of mean, $\mathrm{n}=20$.
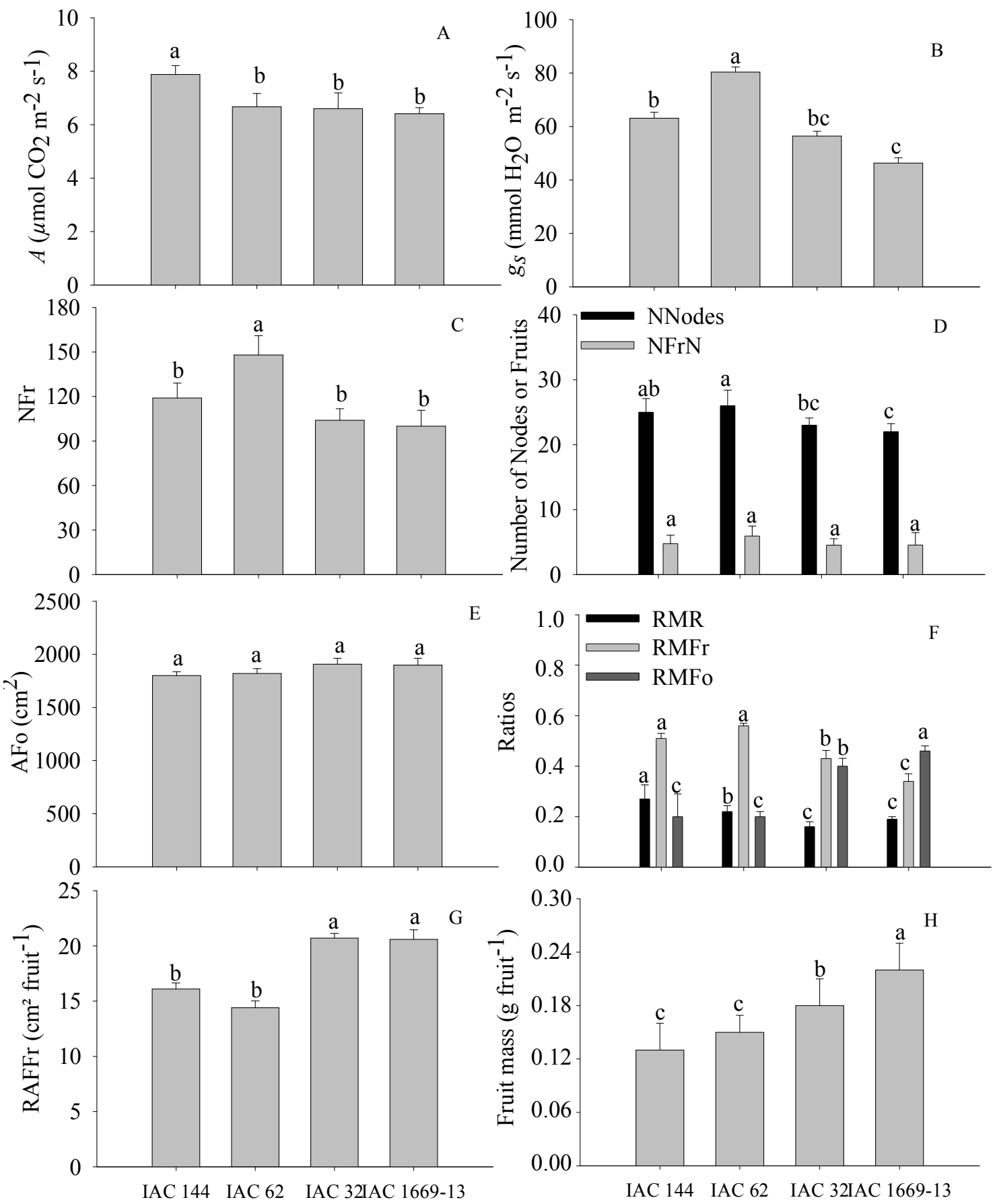

0.30
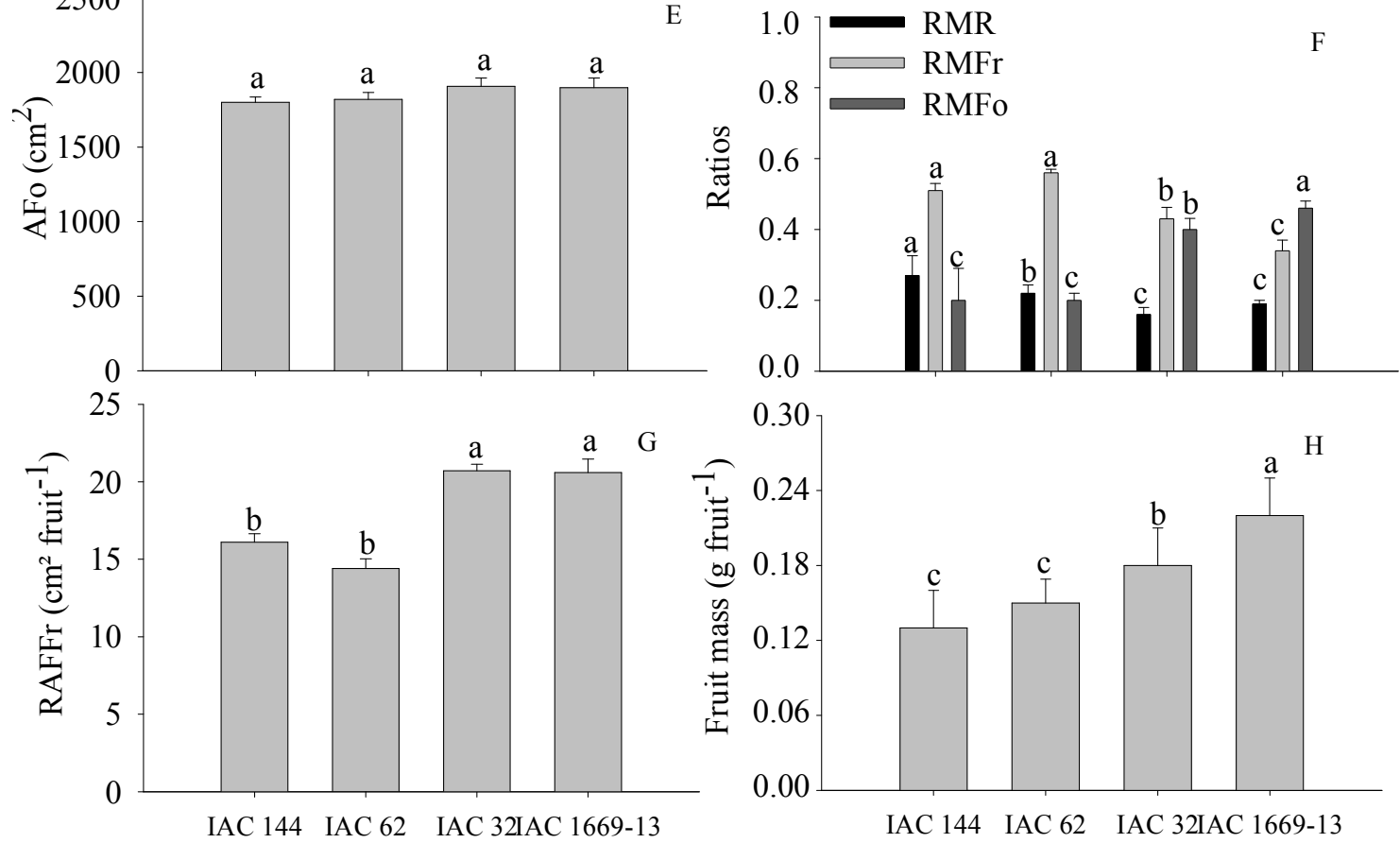
Figure 6. Effect of cultivar factor on variables: $\mathrm{A}$ - net $\mathrm{CO}_{2}$ assimilation rate $(A), \mathrm{B}$ - stomatal conductance $\left(g_{\mathrm{s}}\right), \mathrm{C}-$ number of fruits per branch (NFr), D - number of nodes per branch (NNodes) and fruit per node (NFrN), E - leaf area of the branch (AFo), $\mathrm{F}$ - mass ratios of branch (RMR), fruits (RMFr) and leaves (RMFo), G - relationship between leaf area and number of fruits per branch (RAFFr), and $\mathrm{H}$ - fruit mass in April 2014 in Rio Paranaiba, MG. Columns followed by the same letter do not differ by the Tukey test at $5 \%$ probability. Each column refers to the average \pm standard error of mean, $\mathrm{n}=20$.
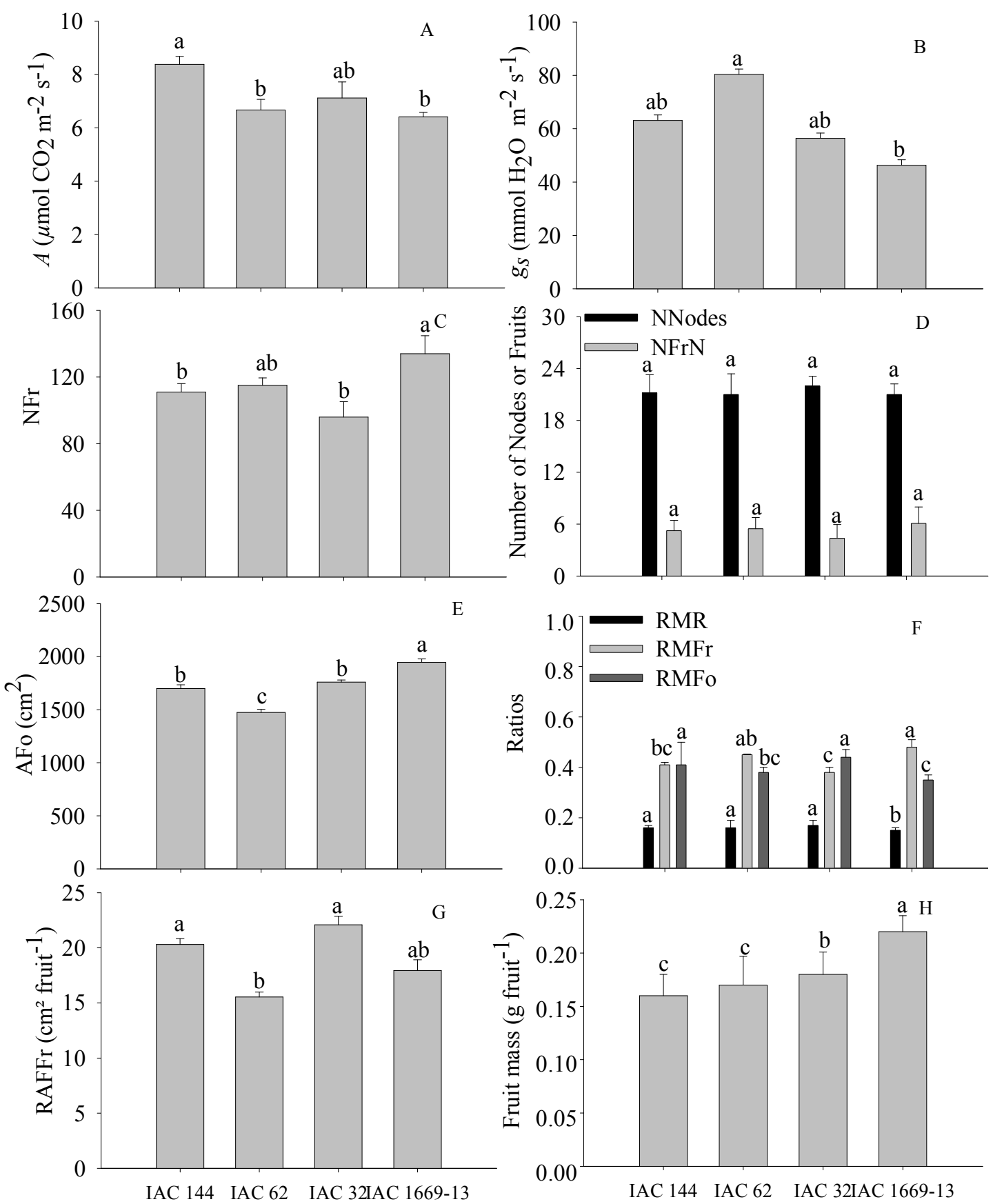
When comparing cultivars, regardless of spacing and branch position, morphophysiological relations among some variables were observed, in plagiotropic branches within the same evaluation period, but this pattern was rarely repeated in all evaluation periods (Figures 4, 5 and 6), thereby limiting the comparison among cultivars. The different responses for each variable show the high plasticity and adaptability shown by Coffea arabica cultivars in differing environmental conditions (BOTELHO et al., 2010; NASCIMENTO et al., 2010; RODRIGUES et al., 2014). Although significant differences among cultivars in the number of nodes per branch (NNodes) and number of fruits per node (NFrN) were not observed, mainly in assessments made in the final period of fruit filling (April 2013 - Figure 4 D and April 2014 - Figure 6 D), IAC 1669-13 cultivar showed higher NFr than the others in April 2013 (Figure 4 C), and equal to IAC 62, but higher than IAC 144 and IAC 32 in April 2014 (Figure 6 C). This may in fact occur given that the NFr is the product of NNodes and NFrN (CANNELL, 1985). It should be noted that the low NFrN observed in this work is because both productive and non-productive nodes have been considered in the calculation of all nodes in the plagiotropic branch.

The above results explain, at least partially, the higher matter partitioned for fruits as against the plagiotropic stem in IAC 1669-13 cultivar compared to the others (comparing RMfr and RMR among cultivars in Figure 4 and Figure 6 F) in the same evaluation periods (April 2013 and 2014). In addition, in April 2013, the higher NFr in IAC 1669-13 cultivar was responsible for the lower RAFFr in this cultivar (Figure $4 \mathrm{G}$ ), as compared to the others, given that there was no change in leaf area (AFo) among cultivars in this period (Figure 4 E). Despite the low RAFFr, the dry matter weight per fruit in April 2013 (Figure $4 \mathrm{H}$ ) was not reduced in IAC 1669-13, being the highest in December 2013 (Figure 5 H) and April 2014 (Figure 6 H) among cultivars. This was in spite of this cultivar presenting the lowest $A$ (Figure 4) associated with lower $g_{\mathrm{s}}$ (Figure $4 \mathrm{~B}$ ), compared, for example, to IAC 144. The cultivar IAC 1669-13 presented the best morphological attributes related to absorption of water and nutrients from the root system in comparison to the other cultivars, especially IAC 144 (RONCHI et al., 2015b). This associated with the likely absence or low autonomy of the plagiotropic branch (CHAVES et al., 2012), can offset, in part, this slight imbalance in the source: sink ratio of the branch, ensuring full fruit filling in this cultivar. Moreover, it is noteworthy that IAC 1669-13 has been cultivated in the Cerrado, not only due to its high productivity (BLISKA et al., 2011), but also because of its resistance to rust and the nematode Meloidogyne exigua (CARVALHO, 2008), and for its ability to adapt to different spatial scenarios while maintaining a dense crop (BLISKA et al., 2011).

\section{Conclusions}

The decrease in the number of fruits per plagiotropic branch caused by the reduction in the spacing between plants was due to the reduction in the number of fruits per branch and not to the number of nodes per branch.

Regardless of cultivars and position of the plagiotropic branch, leaf area: fruit ratio increased linearly with the reduction in spacing due to the linear decrease in the number of fruits per branch, therefore featuring the increase in the source: sink ratio in denser crops.

The parameters of gas exchange, fluorescence and pigments were little or not at all affected by cultivars or spacing.

Levels of carotenoids and chlorophyll $a$ were higher, while the leaf area: fruit ratio was lower in most exposed branches compared to those within the canopy.

The cultivars showed high plasticity for cultivation at different spacing. 


\section{Acknowledgements}

We thank the Foundation for Research of the State of Minas Gerais (Fapemig) for financial support; the Coordination for the Improvement of Higher Education Personnel (Capes) for granting of scholarships; and Fazenda Transagro S.A., for extending availability of the experimental area.

\section{References}

ANDRADE, W. E. B.; GUIMARÃES, P. T. G.; FAQUIN, V.; GUIMARÃES, R. J. Produtividade do cafeeiro arábica em condições de adensamento, no noroeste fluminense. Coffee Science, Lavras, v. 9, n.1, p. 90-101, 2014.

ARAUJO, W. L.; DIAS, P. C.; MORAES, G. A. B. K.; CELIN, E. F.; CUNHA, R. L.; BARROS, R. S.; DaMATTA, F. M. Limitations to photosynthesis in coffee leaves from different canopy positions. Plant Physiology and Biochemistry, Bari, v. 46, n. 10, p. 884-890, 2008.

AUGUSTO, H. S.; MARTINEZ, H. E. P.; SAMPAIO, N. F.; CRUZ, C. D.; PEDROSA, A. W. Produtividade de cultivares de café (Coffea arabica L.) sob espaçamentos adensados. Revista Ceres, Viçosa, MG, v. 53, n. 309, p. 539-547, 2006.

BLISKA, F. M. M.; FAZUOLI, L. C.; BRAGHINI, M. T. Impactos de cultivares resistentes a doenças e pragas no desenvolvimento sustentável da cafeicultura nas principais regiões cafeeiras do brasil. In: SIMPÓSIO DE PESQUISA DOS CAFÉS DO BRASIL, 7., 2011, Araxá. Anais... Brasília: EMBRAPA-Café, 2011. 7 p. 1 CD-ROM.

BOTELHO, C. E.; REZENDE, J. D.; CARVALHO, G. R.; CARVALHO, A. D.; ANDRADE, V. T.; BARBOSA, C. R. Adaptabilidade e estabilidade fenotípica de cultivares de café arábica em Minas Gerais. Pesquisa Agropecuária Brasileira, Brasília, v. 45, n. 12, p. 1404-1411, 2010.

CANNELL, M. G. Physiology of the coffee crop. In: CLIFFORD, M. N.; WILSON, K. C. (Ed.). Coffee: botany, biochemistry and production of beans and beverage. London: Crom Helm, 1985. p. 108-134.

CARVALHO, C. H. S. de. Cultivares de café: origem, características e recomendações. Brasília: EMBRAPA, 2008. 334 p.

CHAVES, A. R. M.; MARTINS, S. C.; BATISTA, K. D.; CELIN, E. F.; DaMATTA, F. M. Varying leaf-to-fruit ratios affect branch growth and dieback, with little to no effect on photosynthesis, carbohydrate or mineral pools, in different canopy positions of field-grown coffee trees.
Environmental and Experimental Botany, Lancaster, v. 77, n. 1, p. 207-218, 2012.

COMPANHIA NACIONAL DE ABASTECIMENTO - CONAB. Acompanhamento da safra Brasileira: café safra 2016 primeiro levantamento. Brasília: Conab, 2016. Disponível em: <http://www.conab.gov.br/OlalaCMS/ uploads/arquivos/16_01_20_09_24_06_boletim_cafe_janeiro_2016.pdf>. Acesso em: 17 mar. 2016.

DaMATTA, F. M. Ecophysiological constraints on the production of shaded and unshaded coffee: a review. Field Crops Research, Warwick, v. 86, n. 2-3, p. 99-114, 2004.

DaMATTA, F. M.; CUNHA, R. L.; ANTUNES, W. C.; MARTINS, S. C. V.; ARAÚJO, W. L.; FERNIE, A.; MORAES, G. A. B. K. In field-grown coffee trees source-sink manipulation alters photosynthetic rates, independently of carbon metabolism, via alterations in stomatal function. New Phytologist, Cambridge, v. 178, n. 2, p. 348-357, 2008.

DaMATTA, F. M.; RONCHI, C. P.; MAESTRI, M.; BARROS, R. S. Ecophysiology of coffee growth and production. Brazilian Journal of Plant Physiology, Londrina, v. 19, n. 4, p. 485-510, 2007.

FAHL, J. I.; CARELLI, M. L. C.; QUEIROZ-VOLTAN, R. B.; DIAS, A. A.; CAMARGO, M. B. P. D. Efeitos de níveis de luz na floração, frutificação e produtividade de Coffea arabica. In: SIMPÓSIO DE PESQUISA DOS CAFÉS DO BRASIL, 6., 2009, Vitória. Anais... Brasília: EMBRAPA - Café, 2009. p. 87-106.

FERNANDES, A. L. T.; PARTELLI, F. L.; BONOMO, R.; GOLYNSKI, A. A. Moderna cafeicultura dos cerrados brasileiros. Pesquisa Agropecuária Tropical, Goiânia, v. 42, n. 2, p. 231-240, 2012.

FERREIRA, E. P. B.; PARTELLI, F. L.; DIDONET,A. D.; MARRA, G. E. R.; BRAUN, H. Crescimento vegetativo de Coffea arabica L. influenciado por irrigação e fatores climáticos no Cerrado Goiano. Semina: Ciências Agrárias, Londrina, v. 34, n. 6, p. 3235-3244, 2013.

FRANCK, N.; VAAST, P.; GÉNARD, M.; DAUZAT, J. Soluble sugars mediate sink feedback down-regulation of leaf photosynthesis in field-grown Coffea arabica. Tree Physiology, Victoria, v. 26, n. 4, p. 517-525, 2006.

LAVIOLA, B. G.; MARTINEZ, H. E. P.; SALOMÃO, L. C. C.; CRUZ, C. D.; MENDONÇA, S. M.; PAULA, N. Alocação de fotoassimilados em folhas e frutos de cafeeiro cultivado em duas altitudes. Pesquisa Agropecuária Brasileira, Brasília, v. 42, n. 11, p. 15211530, 2007. 
MATIELLO, J. B.; SANTINATO, R.; GARCIA, A. W. R.; ALMEIDA, S. R.; FERNANDES, D. R. Cultura de café no Brasil: manual de recomendações. Rio de Janeiro, Varginha, MG: MAPA/PROCAFE, 2010. 546 p.

MATOS, F. S.; WOLFGRAMM, R.; GONÇALVES, F. V.; CAVATTE, P. C.; VENTRELLA, M. C.; DaMATTA, F. M. Phenotypic plasticity in response to light in the coffee tree. Environmental and Experimental Botany, Lancaster, v. 67, n. 2, p. 421-427, 2009.

MORAIS, H.; CARAMORI, P. H.; KOGUISHI, M. S.; RIBEIRO, A. M. D. A. Escala fenológica detalhada da fase reprodutiva de Coffea arabica. Bragantia, Campinas, v. 67, n. 1, p. 257-260, 2008.

MOTTA, P. E. F.; BARUQUI, A. M.; SANTOS, H. G. Levantamento de reconhecimento de média intensidade dos solos da região do Alto Paranaíba, Minas Gerais. Rio de Janeiro: EMBRAPA Solos, 2004. 414 p. (Boletim de Pesquisa e Desenvolvimento, 44).

NASCIMENTO, E. A.; OLIVEIRA, L. E. M.; CASTRO, E. M.; DELÚ FILHO, N.; MESQUITA, A. C.; VIEIRA, C. V. Alterações morfofisiológicas em folhas de cafeeiro (Coffea arabica L.) consorciado com seringueira (Hevea brasiliensis Muell. Arg.). Ciência Rural, Santa Maria, v. 36, n. 3, p. 852-857, 2006.

NASCIMENTO, M.; FERREIRA, A.; FERRÃO, R. G.; CAMPANA, A. C. M.; BHERING, L. L.; CRUZ, C. D.; FERRÃO, M. A. G.; FONSECA, A. F. A. Adaptabilidade e estabilidade via regressão não paramétrica em genótipos de café. Pesquisa Agropecuária Brasileira, Brasília, v. 45, n. 1, p. 41-48, 2010.

PARTELLI, F. L.; ARAÚJO, A. V.; VIEIRA, H. D.; DIAS, J. R. M.; MENEZES, L. F. T.; RAMALHO, J. C. Microclimate and development of Conilon coffee intercropped with rubber trees. Pesquisa Agropecuária Brasileira, Brasília, v. 49, n. 11, p. 872-881, 2014.

PAULO, E. M.; FURLANI JUNIOR, E.; FAZUOLI, L. C. Comportamento de cultivares de cafeeiro em diferentes densidades de plantio. Bragantia, Campinas, v. 64, N. 3 , p. 397-409, 2005.

PEREIRA, S. P.; BALIZA, D. P.; SANTOS, M. O.; ALVES, J. D.; GUIMARÃES, R. J. Influência do espaçamento de cultivo em duas épocas de poda nos teores caulinares de carboidratos em cafeeiros. Coffee Science, Lavras, v. 8, n. 4, p. 460-468, 2013.

PEREIRA, S. P.; BARTHOLO, G. F.; BALIZA, D. P.; SOBREIRA, F. M.; GUIMARÃES, R. J. Crescimento, produtividade e bienalidade do cafeeiro em função do espaçamento de cultivo. Pesquisa Agropecuária Brasileira, Brasília, v. 46, n. 2, p. 152-160, 2011.
PEREIRA, S. P.; CUNHA, R. L. Caracterização fenológica e reprodutiva de cafeeiros em diversos espancamentos, antes e após a poda. 2004. Dissertação (Mestrado em Fitotecnia) - Universidade Federal de Lavras, Lavras.

RENA, A. B.; NACIF, A. P.; GUIMARÃES, P. T. G. Fenologia, produtividade e análise econômica do cafeeiro em cultivos com diferentes densidades de plantio e doses de fertilizantes. In: ZAMBOLIM, L. Produção integrada de café. Viçosa, MG: UFV, 2003. p. 133-196.

RODRIGUES, W. P.; VIEIRA, H. D.; BARBOSA, D. H. S. G.; SOUSA FILHO, G. R.; PARTELLI, F. L. Agronomic performance of arabica coffee genotypes in northwest Rio de Janeiro State. Genetics and Molecular Research, Riberão Preto, v. 13, n. 3, p. 5664-5673, 2014.

RODRÍGUEZ-LÓPEZ，N. F.; MARTINS，S. C. V.; CAVATTE, P. C.; SILVA, P. E. M.; MORAIS, L. E.; PEREIRA, L. F.; REIS, J. V.; ÁVILA, R. T.; GODOY, A. G.; LAVINSKI, A. O.; DaMATTA, F. M. Morphological and physiological acclimations of coffee seedlings to growth over a range of fixed or changing light supplies. Environmental and Experimental Botany, Lancaster, v. 102, n. 1, p. 1-10, 2014.

RONCHI, C. P.; ARAÚJO, F. C. de; ALMEIDA, W. L. de; SILVA, M. A. A. da; MAGALHÃES, C. E. O. de; OLIVEIRA, L. B. de; DRUMOND, L. C. D. Respostas ecofisiológicas de cafeeiros submetidos ao deficit hídrico para concentração da florada no Cerrado mineiro. Pesquisa Agropecuária Brasileira, Brasília, v. 50, n. 1, p. 24-32, 2015a.

RONCHI, C. P.; DaMATTA, F. M.; BATISTA, K. D.; MORAES, G. A.; LOUREIRO, M. E.; DUCATTI, C. Growth and photosynthetic down-regulation in Coffea arabica in response to restricted root volume. Functional Plant Biology, Collingwood, v. 33, n. 11, p. 1013-1023, 2006.

RONCHI, C. P.; SOUSA JÚNIOR, J. M. de; ALMEIDA, W. L. de; SOUZA, D. S.; SILVA, N. O.; OLIVEIRA, L. B. de; GUERRA, A. M. N. M. Morfologia radicular de cultivares de café arábica submetidos a diferentes arranjos espaciais Pesquisa Agropecuária Brasileira, Brasília, v. 50, n. 3, p. 187-195, 2015 b.

SANTINATO, R.; FERNANDS, A. L. T.; FERNANDES, D. R. Irrigação na cultura do café. 2. ed. Belo Horizonte: Editora O Lutador, 2008. 476 p.

TATAGIBA, S. D.; PEZZOPANE, J. E. M.; REIS, E. F. Crescimento vegetativo de mudas de café arábica (Coffea arabica L.) submetidas a diferentes níveis de sombreamento. Coffee Science, Lavras, v. 5, n. 3, p. 251261,2010 . 
VAAST, P.; ANGRAND, J.; FRANCK, N.; DAUZAT, J.; GÉNARD, M. Fruit load and branch ring-barking affect carbon allocation and photosynthesis of leaf and fruit of Coffea arabica in the field. Tree Physiology, Victoria, v. 25, n. 6, p. 753-760, 2005.
VAAST, P.; BERTRAND, B.; PERRIOT, J. J.; GUYOT, B.; GÉNARD, M. Fruit thinning and shade improve bean characteristics and beverage quality of coffee (Coffea arabica L.) under optimal conditions. Journal of the Science of Food and Agriculture, Malden, v. 86, n. 2, p. 197-204, 2006. 